\title{
Entrepreneurship Verses Reinterpretation of Qur'an Surah Quraisy Based on Humanism Hassan Hanafi Theology
}

\author{
Abdul Karim \\ IAIN Kudus, Center Java, Indonesia \\ karim@iainkudus.ac.id \\ Yuyun Afandi \\ UIN Walisongo Semarang, Center Java, Indonesia \\ yuyunaffandi@walisongo.ac.id
}

\section{Abstract}

This qualitative research aims to comprehensively determine the gap between classical and contemporary interpretations of Qur'an Surah Quraisy that needs to be decomposed with the theological theory of humanism Hassan Hanafi, using the tahlili-muqaran interpretation method. The study found that the difference was apparent in explaining the term with the classical and modern interpretation methods used to define ilaf as habit or love and expertise in entrepreneurship, respectively. Furthermore, the word "Quraisy" is interpreted as a tribal name according to classical interpretation and branding in accordance with modern interpretations. The word rihlah is interpreted as a trade trip by classical interpretations, while in modern interpretation, it is known as an effort to maintain and improve quality. The word worship is interpreted as vertical and horizontal relationships by classical and modern interpretations, respectively. The differences are analyzed with the humanistic theology of Hassan Hanafi's four points including, dialectics, eclectic, hermeneutics, and phenomenology. This research provides a new contribution to the 
interpretation of tahlili in collaboration with muqaran. It also tries to determine a common ground between classical and modern interpretations.

Keyword: Theology, Humanism, Hassan Hanafi, Quraisy.

\section{Abstrak}

REINTERPRETASI AYAT KEWIRAUSAHAAN DALAM AL-QUR'AN SURAH QURAISY BERDASARKAN TEOLOGI HUMANISME HASSAN HANAFI. Artikel kualitatif ini menggunakan metode penafsiran tahlili-muqaran. Artikel ini bermaksud menelusuri lebih mendalam perbedaan penafsiran klasik dan modern tentang Al-Qur'an Surah Quraisy. Problem akademik dalam penelitian ini adalah terjadinya gap antara tafsir klasik dan kontemporer dalam memahami AlQur'an Surah Quraisy yang perlu sekali untuk diurai dengan teori teologi humanisme Hassan Hanafi. Penulis menemukan bahwa perbedaan itu terlihat sekali dalam menjelaskan istilah. Kata ilaf cenderung dimaknai sebagai kebiasaan atau cinta oleh tafsir klasik. Sementara, tafsir modern menyebutnya sebagai keahlian dalam berwirausaha. Kata "Quraisy" cenderung diartikan sebagai nama suku menurut tafsir klasik. Sementara, tafsir modern menyebutnya sebagai branding. Kata rihlah diartikan sebagai perjalanan dagang oleh tafsir klasik. Tafsir modern menyebutnya sebagai upaya menjaga kualitas dan meningkatkannya. Kata "ibadah" diartikan sebagai hubungan vertikal oleh tafsir klasik. Sementara, tafsir modern menyebutnya sebagai hubungan horisontal. Perbedaan itu bisa dianalisis dengan menggunakan teologi humanisme Hassan Hanafi yang memiliki empat poin, yaitu dialektika, eklektika, hermeneutika, dan fenomonologi. Artikel ini memberikan kontribusi baru sebagai tafsir tahlili yang dikolaborasikan dengan tafsir muqaran. Selain itu, kajian dalam artikel ini juga berupaya mencari titik temu antara tafsir klasik dan modern.

Kata Kunci: Teologi, Humanisme, Hassan Hanafi, Quraisy.

\section{A. Introduction}

Entrepreneurship is an interesting theme in Islamic studies, which links with the spirit of studying the Qur'an. ${ }^{1}$ The entrepreneurship study in Islam is associated with the teaching of

${ }^{1}$ Sjaroni, “Studi Tafsir Tematik," Jurnal Studi Islam: Pancawahana, 2014, 1. 
faith, worship, and relationship with God. ${ }^{2}$ This is because Islam is not only a religion that talks about prayer, fasting, pilgrimage, and ritual worship, it also provides teachings on charity business. History also records that the Prophet Muhammad was a formidable trader and an entrepreneur. ${ }^{3}$

Research on entrepreneurship has been widely carried out, for example journal articles written by Fikri Maulana on "Entrepreneurship Education in Islam". This study used a thematic interpretation method to obtain motivational points in entrepreneurship according to the Qur'an and Hadith. ${ }^{4}$ Juhanis research found that the key to the entrepreneurship success of Prophet Muhammad was his attitude in building enchanting relationships associated with honest, trustful, intelligent, and tabligh characters (saying the truth). According to Prophet Muhammad, these qualities are very necessary to be applied also for entrepreneurs. ${ }^{5}$

A journal article was also written by Miles K. Davis entitled "Entrepreneurship: an Islamic Perspective". In this article, Davis explained the reason for the importance of studying entrepreneurship theory and an entrepreneur's behavior from an Islamic perspective. ${ }^{6}$ Zainal Abidin also reinforced that the values of honesty, hard work, building relationships properly, respecting others, and not being ashamed to try were the soul and mental entrepreneur of Islam. ${ }^{7}$ Research by Miles K. Devis has relevance to the theme of this current study, however, it is certainly very different in terms of paradigm, methodology, and approach.

${ }^{2}$ Ali Aslan Gümüsay, "Entrepreneurship from an Islamic Perspective," Journal of Business Ethics, 2015, 1, doi:10.1007/s10551-014-2223-7.

${ }^{3}$ Nur Baladina, "Membangun Konsep Enterpreneurship Islam," ULUL ALBAB: Jurnal Studi Islam 13, no. 2 (2013): 123.

${ }^{4}$ Fikri Maulana, "Pendidikan Kewirausahaan Dalam Islam," IQ (Ilmu Al-Quran): Jurnal Pendidikan Islam 2, no. 01, (2019): 31.

${ }^{5} J u h a n i s$, "Filosofi Wirausaha Nabi Muhamad," SULESANA: Jurnal Wawasan Keislaman 8, no. 1 (2013): 1.

${ }^{6}$ Miles K. Davis, "Entrepreneurship: an Islamic Perspective," International Journal Entrepreneurship and Small Business 20, no. 2 (2013): 64-66.

${ }^{7}$ Zainal Abidin and Ari Wahyu Prananta, "Kajian Etos Kerja Islami Dalam Menumbuhkan Jiwa Wirausaha Santri," Happiness, Journal of Psychology and Islamic Science 3, no. 2 (2019): 5. 
The Qur'an Surah Quraisy was reviewed with a theological basis of humanism Hassan Hanafi in order to implement the faith of those that have a vertical relationship with God Almighty (hablun min Allah), as well as direct and tangible actions related to humanity/horizontal (hablun min an-nas). This theory is used as an effort to answer the ignorance and Muslims thinking of the establishment of religious knowledge. According to Hassan Hanafi, there needs to be actions from Muslims that are not only concerned with texts but also show real actions in their social behavior. ${ }^{8}$

This research found the relevance of Hassan Hanafi's theological concept of humanism with a shift in the interpretation of Q.S. Quraisy performed by classical scholars such as Ibn Kathir, ath-Tabari, ar-Razi, al-Mawardi, asy-Syaukani. It is also associated with modern scholars in the interpretation of al-Maraghi, al-Munir by Wahbah az-Zuhaili, and al-Misbah by M. Quraish Shihab, and commentary released by the Indonesian Ministry of Religion. ${ }^{9}$

This research aims to provide benefits that are able to contribute to the application of social theories provided by modern Islamic thinkers. Therefore, contemporary researchers need to use the theory to decipher current social issues. Few studies focus on such matters, therefore, this research type greatly contributes to enriching the Islamic treasures and solving problems associated with bridging classical and modern interpretations.

The fundamental questions of this research are associated with how the entrepreneurial verses in the Q.S. Quraisy is interpreted according to the classical books and on the basis of Hassan Hanafi's humanism theology.

This is descriptive qualitative and critical research, with data secondary data collected from several references related to the Hassan Hanafi thoughts and the interpretation of Q.S. Quraisy from libraries. The study aims to determine the classical and modern

\footnotetext{
${ }^{8}$ Moh. Sholehuddin, "Metode Ushul Fiqih Hasan Hanafi," Journal de Jure, 2011: 1, http://dx.doi.org/10.18860/j-fsh.v3i2.2148. 2011).

${ }^{9}$ Departemen Agama RI, Al-Quran Dan Tafsirnya, Jilid 10 (Jakarta: Widya Cahaya,
} 
interpretation data, make comparisons, and look for different points as well as similarities. Furthermore, the study also provides alternative meanings from several interpretations to obtain the relevance of the dynamics of Qur'anic interpretation.

This research utilized the tafsir tahlili-muqaran research method. According to al-Farmawi, tahlili is a method of interpreting Qur'anic verses by explaining all aspects and meanings in accordance with the competence and tendencies of the mufassir. Meanwhile, muqaran is an interpretation method used to explain the verses of the Qur'an based on the books written by the mufassir by collecting several Qur'anic verses in one discussion, which expresses and discusses the mufassir's opinions on these verses in both classical and modern scholars. ${ }^{10}$ Therefore, the tafsir tahlili-muqaran is the interpretation of the Qur'anic verses in detail, which is taken from the order in accordance with the manuscripts of the Qur'an.

\section{B. Discussion}

\section{Theological Theory of Hassan Hanafi Humanism}

The Hassan Hanafi humanism concept is a human-centered theology that is not only related to the discussion of God Almighty and nature, rather it also talks about humans as central to life. In order to deal with contemporary problems, humans need to become the main axis in their studies. ${ }^{11}$

Methodologically, Hassan Hanafi's humanistic thinking is oriented to pragmatism, which is reasoning thinking based on social reality problems that aim to contribute to the solutions of social life. Therefore, Hassan Hanafi desired to produce a social change to better and dignified human interest and to change theocentric to anthropocentrism theology. ${ }^{12}$

\footnotetext{
${ }^{10}$ Abdul Hayy al-Farmawi, al-Bidayah fi at-Tafsir Maudhui: Dirasah Manhajiyyah Maudhuiyyah (Mesir: Mathba'ah al-Hadharah al-Arabiyyah, 1997), 24.

${ }^{11}$ Hassan Hanafi, Islamologi 3: Dari Teosentris Ke Antroposentris (Yogyakarta: LKiS, 2004), 69.

${ }^{12}$ Riza Zahriyal Falah and Irzum Farihah, "Pemikiran Teologi Hassan Hanafi," Fikrah: Jurnal Ilmu Aqidah Dan Studi Keagamaan, 2016, doi:10.21043/fikrah.v3i1.1833.
} 
The four factors that became the rationale and methodology of Hassan Hanafi's humanistic theology. The first is the dialectics method by the philosophy of Marxism. ${ }^{13}$ This method is used to reconstruct the theological revolution theory that is touted, with dialectics used to determine and investigate changes in nature, society, and thought. The method analyzes the arguments of one phenomenon, therefore, Hassan Hanafi used it to re-dialogue the established concept of monotheism, which was understood in the past. ${ }^{14}$

The second is the hermeneutic method used by Hassan Hanafi to understand Islamic religious texts. ${ }^{15}$ Hassan was greatly influenced by Western hermeneutic methods, a methodological instrument that shifts revelation from theoretical, letters, and logos to the praxis and reality levels to answer the problems of life and provide solutions. Some stated that Hassan Hanafi followed Gadamer hermeneutics, ${ }^{15}$ while others reported that Hassan has a critical hermeneutic school known as Habermas. However, the most important thing is that Hassan has a tendency to reinterpret established texts and disagrees with the Schleiermacher objectivity school.

The third is the phenomenological method, which analyzes social, community, political and economic realities. This knowledge departs from self-awareness and its development towards the selfrecognition of humanity and their surroundings. The method also intends to search for meaning from one particular phenomenon, which actually becomes the basis of dialectics philosophy. Hassan Hanafi wanted to convey three types of awareness, namely self, religious texts, and social reality. ${ }^{16}$

The fourth is the eclectic method, which is the selection and integration of the best and most suitable methods for supporting its mission in fueling the spirit of theological revolution. Hanafi stated

${ }^{13}$ A.H. Ridwan, Reformasi Intelektual Islam: Pemikiran Hassan Hanafi Tentang Reaktualisasi Tradisi Keilmuan Islam (Yogyakarta: ITTAQA Press, 1998), 18-24.

${ }^{14}$ Falah and Farihah, "Pemikiran Teologi Hassan Hanafi."

${ }^{15}$ Ahmad Zayyadi, "Pendekatan Hermeneutika Al-Qur'an Kontemporer Nashr Hamid Abu Zaid," MAGHZA: Jurnal Ilmu Al-Qur'an dan Tafsir, 2018, 1, http:// dx.doi.org/10.24090/maghza.v2i1.1563.

${ }^{16}$ Falah and Farihah, "Pemikiran Teologi Hassan Hanafi." 
that theology is not only personal-individual or pious, rather it is also humanistic and social pious. Hassan Hanafi thoughts awakened in humanism theology using the following methods. ${ }^{17}$

\section{Entrepreneurship Versus Interpretation in Q.S. Quraisy According to the Classical and Modern Interpretations Books}

The Q.S. Quraisy:

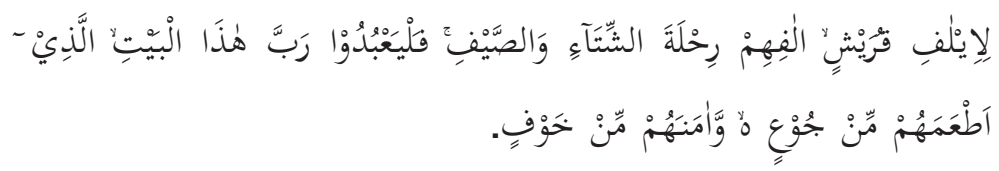

"Since the Quraisy became accustomed (1), to the journey of winter and summer (2), let them worship the Lord in this House (3) , that fed them against hunger, and fear (4)." (Q.S. Quraisy [106]: 1-4). ${ }^{18}$

Ar-Razi provides a narrative of the relationship between Surah Quraisy and Surah al-Fil, which is associated with the habit of trading abroad. According to ar-Razi, Quraisy get respect and glory from neighboring countries because they are considered the family of Allah with the privilege of serving the Kaaba. However, Abraha intended to destroy the Kaaba, and assuming the mission was successful, other nations were going to underrate the Arabs. However, Abraha was destroyed by Allah, which made the virtue, authority, and market share of the Quraisy to become stronger. ${ }^{19}$

Ar-Razi presents three opinions on the meaning of ilaf. Firstly, ilaf means ilzam, and the Quraisy set the journey for continuous and uninterrupted trading. Secondly, it means luzum, because the Quraisy always lives in Makah, which is in line with Q.S. al-Anfal [8]: 63 that Allah Almighty melts the hearts of His servants. Similarly, the Quraisy

${ }^{17}$ Ahmad Zainuddin, “Dimensi Sosial Tauhid: Konstruksi Jaringan Relasional Islam Perspektif Hassan Hanafi,” MIYAH: Jurnal Studi Islam 13, no. 1 (2019), 58-81.

${ }^{18}$ Kementrian Agama RI Lajnah Pentashihan Mushaf Al-Quran, Al-Quran Dan Terjemahnya (Bandung: Penerbit J-ART, 2005), 603.

${ }^{19}$ Fakhr ad-Din ar-Razi, Mafatih al-Ghaib (Beirut: Dar al-Kutub al-'Ilmiyah, 2015). 
people were also advised by Allah not to move from Makah. Thirdly, ilaf means the preparations made by the Quraisy to travel. ${ }^{20}$

Ath-Thabari explains that the word ilaf has multiple meanings. Firstly, it is interpreted as a blessing. The purpose of the verse is that Allah has blessed the Quraisy people by traveling in different winters and droughts. Secondly, ilaf is interpreted as ulfah, which means hospitality, brotherhood, and unity of the Quraisy with each other. ${ }^{21}$ Ath-Thabari also stated that the rihlah (journey) of the Quraisy was divided into two trading areas. In summer, they visit Sham, while during winter, they go to Yemen. Furthermore, Allah asked them to apply the Baitullah in these two journeys to provide security and food. ${ }^{22}$

Asy-Syaukani explained that the word li ilafi is still related to the previous letter, namely Q.S. al-Fil. The destruction of the elephant army was an opportunity for the Quraisy to carry out their habit of trading safely. ${ }^{23}$ This is in line with as-Samarqandi, interpretation of the word ilaf as settled. Furthermore, this letter is still related to Q.S. al-Fil, which narrates Allah's reason for destroying the elephant army, was for the Quraisy to settle in Mecca. Therefore, they continue to travel to Sham and Yemen to trade. ${ }^{24}$

Al-Mawardi stated that the word ilaf is interpreted as a customary common habit. This is a unique interpretation that explicitly points to tradition as the meaning of the word ilaf. There are four opinions for the word Quraisy, including gathering, working, research, and the name of a large marine animal. The word rihlah means to travel with two opinions in this regard, namely: (a) taking a trip to Palestine, (b) to Yemen and Sham. ${ }^{25}$ Meanwhile, there are three

\footnotetext{
${ }^{20}$ Ar-Razi.

${ }^{21} \mathrm{Abu} J a$ 'far Muhammad ibn Jarir ath-Thabari, Jami' al-Bayan 'an Ta'wil Ay Al-Qur'an (Giza: Dar al-Hijr, 2001).

${ }^{22}$ Ath-Thabari.

${ }^{23}$ Muhamad bin Ali asy-Syaukani, Fathu al-Qadir (Bairut: Dar al-Kalim ath-Thayyib, 1994), 610 .

${ }^{24}$ Abul Lais Nashr bin Muhamad as-Samarqandi, Bahru al-'Ulum (Bairut: Dar alKutub al-'Ilmiyyah, 1993), 623.

${ }^{25}$ Ali bin Muhammad bin Muhammad al-Mawardi, an-Nukat wa al-'Uyun (Bairut: Dar al-Kutub al-'Ilmiyah, 2010), 348.
} 
opinions regarding ath'amahum including feeding: (a) by presenting wealth and property (Ibn Isa's opinion), (b) because of the blessings of Ibrahim's prayer (the opinion of Ibn Abbas r.a.), (c) due to the presence of the Habasyah people that bring food for them. ${ }^{26}$

There are four opinions associated with wa amanahum min khauf which means protecting them from fear, namely: (a) securing them without being abused by others in order to glorify the land of Haram, (b) secure from elephant army attacks known as Habasyah, (c) secure from infectious diseases, namely famous leprosy called judzam, (d) providing security by giving leadership territory because most of the leaders were from the Quraisy. ${ }^{27}$

Syekh al-Jamal stated that the word ilaf means mahabbah (love), ${ }^{28}$ while Ibn Kathir reported that the meaning is association with Quraisy in Mecca. Ilafi also means a known journey usually carried out Yemen and Sham during the rainy and dry seasons, respectively. They returned to Mecca safely because they were a respectable tribe in the view of humanity that occupies Allah's illegitimate land. Anyone associated with them is glorified and protected. ${ }^{29}$

Ibn Kathir's interpretation is close to the scholars opinion by stating that the word ilaf means to settle in Mecca. However, Ibn focused on the Quraisy gathering in Mecca safely and when further analyzed the purpose of the association was also luzum (settled) Mecca. This is certainly different from the previous interpretation, which stated that Quraisy means gathering. This is because combining the two interpretations produces the meaning of the gathered assembly. However, this is not appropriate for a narrative interpretation of Qur'anic verses because there is a repetition.

Lam in the word li ilafi means amazed. It is associated with questions on how the Quraisy people blessed with security by Allah

\footnotetext{
${ }^{26}$ Al-Mawardi.

${ }^{27}$ Al-Mawardi.

${ }^{28}$ Sulaiman bin Umar bin Manshur al-Jamal, al-Futuhat al-Ilahiyyah (Bairut: Dar alKutub al-'Ilmiyyah, 2018), 412.

${ }^{29} \mathrm{Abu}$ al-Fida Ismail Ibn Katsir, Tafsir Al-Qur'an Al-'Azhim (Riyadh: Dar Taiba, 2006), 491.
} 
easily gained fortune and blessed with brotherhood relationship (silaturrahm). However, they are still ungrateful ( $k u f r$ ) to Allah and worship idols without referencing the Lord that owns the Ka'bah Baitullah. This interpretation tends to direct the word ilaf as a commercial journey that they keep on doing. ${ }^{30}$

Several studies regarding the interpretations of the word ilaf include loving, pursing, and familiarizing work with a variety of experiences that have become a tradition passed down from generation to generation by the Quraisy community. Meanwhile, the word Quraisy is more dominant to the personal meaning of the Kinanah descendants that became the ancestor of the Arabs at that time. The purpose referred to in the verse is directed by the majority of classical commentators as a journey (safar) for their intentions. Some attributed it to Yemen and Sham, however, others called it Bahrain, Ta'if, Palestine, and several other places. Due to their various blessings, God commanded them to give thanks by worshiping Him.

The classical interpretation does not link any Qur'anic verses in the Q.S. Quraisy with the Islamic entrepreneurship theory. This is very understandable because most interpreters are not based on being traders and entrepreneurs. Furthermore, the term entrepreneurship or Islamic entrepreneurship did not exist in their time or was not strongly echoed compared to the current era. This answer is also similar to the reason classical interpreters have little influence on modern social issues like economics and politics.

However, this is dissimilar to the interpretation in the modern era, such as the Ministry of Religious Affairs. This interpretation explains that the Qur'an of Quraisy contains concise guidelines in the economic field, especially those relating to commerce, which is also part of the entrepreneurship. According to this interpretation, analyzing Q.S. Quraisy, help individuals, communities, and countries

${ }^{30} \mathrm{Amin}$ bin Abdullah al-Harari, Hadaiq ar-Ruh wa ar-Raihan (Bairut: Dar Thauq Najah, 2001), 350. 
to achieve prosperity and success in the field of development, with the following conditions: ${ }^{31}$

Firstly, forming a trading spirit by increasing the practice of skills/expertise and education and making it a tradition that is continuously carried out from generation to generation to form an increasingly solid experience, which is the best teacher. This first provision is taken from the meaning of the sentence li ilafi, which means because of habit.

Secondly, success in entrepreneurship by trying to keep the good name of a product also influences the strategies to maintain public/consumer trust. This understanding can be understood from the meaning of the word Quraisy, because the Quraisy tribe is one of the most respected and birthplace of the great leader of Islam, the Prophet Muhammad. As explained in Tafsir al-Mishbah by M. Quraish Shihab, Quraisy is a form of praise for its unity and compactness in the world of commerce, therefore they have strong influence in society. ${ }^{32}$

People tend to go for products from reputable brands, therefore, maintaining a good name is a form of maintaining public or consumer trust in order to remain comfortable and satisfied with the services provided. This creates loyal customers always waiting, for more products and services.

Thirdly, it allowed trade outside the region and abroad, to expand the network and the area of entrepreneurship or business that is being initiated. This is in accordance with the meaning taken and understood from the word rihlah, which means traveling. Entrepreneurs get success to their businesses after expanding their network to establish cooperation with other parties through rihlah such as visits, comparative studies, and MoU. This is similar to the explanation in the interpretation of al-Maraghi, in Surah al-Jumu'ah verse 10, which is a sign of

${ }^{31}$ Departemen Agama RI, Al-Quran Dan Tafsirnya.

${ }^{32}$ M. Quraish Shihab, Tafsir al-Misbah, Volume 15 (Jakarta: Lentera Hati, 2017), 544. 
international trade by instructing God's servants to seek His grace and gifts from various countries. ${ }^{33}$

Fourthly, an entrepreneur needs to be able to take opportunities that can be utilized and generate profits in various situations, conditions, and the surrounding environment. This is associated with the implied meaning of understanding the word asysyita'i wa ash-shaif which means in winter and summer. Therefore, an entrepreneur needs to be able to map the opportunities and challenges faced in certain situations and conditions using good and appropriate marketing techniques to attract customers. However, it needs to be realized that real entrepreneurship is not merely a matter of trade and profit-oriented, it also leads to immaterial things. Therefore, in Q.S. Quraisy is mentioned by falya'budu rabba hadza al-bait which means worship to the owner of Baitullah/Ka'bah, Allah, as explained by Wahbah az-Zuhaili, while interpreting Q.S. al-Jumu'ah [62]: 11, that trade does not rule out the hereafter problem. It means that the spiritual dimension is an inseparable part of entrepreneurial activities. Therefore, the verse explains that the spiritual call to perform the prayer needs to be fulfilled before continuing to trade throughout the world by seeking the gift of God Almighty. ${ }^{34}$

\section{Entrepreneurial Verses Reinterpretation in Q.S. Quraisy based on Humanistic Theology of Hassan Hanafi}

An interesting topic of discussion is the shifting interpretation in the same verses from classical to modern interpretation. This research needs to analyze this change based on the theology of humanism by Hassan Hanafi, which consists of least four points, including dialectic, hermeneutics, phenomenology, and eclectic. These points have strong relevance to the study of Q.S. Quraisy verses 1-4.

\footnotetext{
${ }^{33}$ Ahmad Musthafa al-Maraghi, Tafsir al-Maraghi, Volume 18 (Mesir: Musthafa alBabi al-Halabi, 1946).

${ }^{34}$ Wahbah az-Zuhaili, Tafsir al-Munir fi al-Aqidah wa asy-Syari'ah wa al-Manhaj, Volume 1 (Damaskus: Dar al-Fikr, 2009), 574.
} 
Dialectically, Q.S. Quraisy is not an information point in the Qur'an. This is because, in the interpretation principle, it is stated that not discussing a problem does not mean denying the existence. ${ }^{35}$ This type of thing is often found in logic science.

In the phenomenology study, the work of Arab society generally consists of three kinds: trading, farming, and raising livestock. Trading was usually carried out by urban Arabs that were occupied by the Quraisy. Meanwhile, raising livestock was mostly carried out by marginalized Arabs living in arid rural areas. Meanwhile, farming is mostly carried out by southern Arabs such as Yemen. Furthermore, the Arabs were divided into two villages, Bedouin and Hadhori. In general, the Bedouin tribes lead a nomadic lifestyle by working as sheep and camel herders, hunting and ambushing animals. However, they also desire to maintain their language originality, which is a positive attribute. ${ }^{36}$

The Quraisy community, including Arabs, worked the same as traders from southern Arabia. According to historical data, Hashim was the first person to invite them to trade at Sham and Yemen, which enabled them to make lots of profits. These people did not stop at Mecca as a commercial center or temporary transit point.

However, the caravan trade trip rested in the north of Mecca, precisely the Petra city. This is because in addition to the cool weather, Petra also allows travellers to stop due to the desert heat. Meanwhile, Mecca used to provide rules such as tribute to travellers that stopped by to drink the Zamzam water. This makes them reluctant to transit, thereby making the city quiet and less desirable. ${ }^{37}$

Furthermore, Qushay, better known by the name, became the first driver to open Mecca land for free. ${ }^{38}$ The people of Quraisy welcomed Mujammi decision because it reunited them after the

\footnotetext{
${ }^{35}$ Abdullah bin Mas'ud al-Bukhari, at-Taudhih fi Halli Ghawamidh at-Tanqih (Bairut: Dar al-Kutub al-'Ilmiyah, 2014), 212.

${ }^{36}$ Philip K. Hitti, History of the Arabs (Jakarta: Serambi, 2002), 29.

${ }^{37}$ Syarifuddin, "Analisis Sejarah Dagang Muhammad Pra Kerasulan," Jurnal Ilmiah alSyirah 5, no. 2 (2016): 3.

${ }^{38}$ Syarifuddin, "Analisis Sejarah Dagang Muhammad Pra Kerasulan."
} 
scattered due to the death of Fihr ibn Malik, the forerunner of the Quraisy tribe, as mentioned by some sources. Therefore, Qushay is also known as Mujammi, which means people that gather the Arab nations. ${ }^{39}$

In the past, the key of the Ka'bah was carried by the Khuzaah tribe, and not the Quraisy. However, they were considered a failure to their poor management process, which made the Quraisy tribe to take this role. Therefore, the combination of trading expertise and carrying the key of Kaaba became a new force for them to improve the Mecca city as a center of civilization and trade. This attracted other tribes and foreigners. ${ }^{40}$

Hermeneutically, the word Quraisy experienced development. Hassan Hanafi, and other Islamic thinkers, in line with the Gadamer Hermeneutic school on reader subjectivity, understood that whoever the reader has the right to reinterpret the existing text to be adjusted to the situation and condition of the reader. ${ }^{41}$

There are three ways of interpretation, according to Hassan Hanafi. Firstly, the intellectual heritage and western insight. Secondly, properly understand the religious texts of traditional Islamic heritage. Thirdly, reader needs a sharp analysis and dialectics between Islamic and Western texts in the contextual eras. It is hoped that these texts can dialogue with contemporary problems. Therefore, Hassan Hanafi incorporated this concept in the book at-Turats wa at-Tajdid known as inheritance and renewal. ${ }^{42}$

There is a shift in the meaning of the word Quraisy which is interpreted by classical scholars as people's names, in accordance with the hermeneutic theory adopted by Hassan Hanafi. For example,

${ }^{39}$ Francis E. Peters, Muhammad and the Origins of Islam (Amerika Serikat: SUNY Press, 1994), 16.

${ }^{40}$ Karen Amstrong, Muhamad Sang Nabi: Sebuah Biografi Kritis (Surabaya: Risalah Gusti, 2011), 72.

${ }^{41}$ Muh. Hanif, "Hermeneutika Hans-Georg Gadamer Dan Signifikansinya Terhadap Penafsiran Al-Qur'an," Maghza 7, no. 40 (2013): 95.

${ }^{42}$ Dalmeri, "Membayangkan Islam Dan Toleransi Di Era Postmodernitas: Kritik Terhadap Rasionalisme Kaum Muslim Modernis," HARMONI: Jurnal Multikultural and Multireligius 9, no. 35 (2010): 26. 
it is interpreted as another name by Fihri bin Malik, and some call it other names from an-Nadhr bin Kinanah. Furthermore, Quraisy word relevance to entrepreneurship, interpreted it as branding or the big name of a business. According to the interpretation of the Indonesian Ministry of Religious Affairs, Quraisy has a good meaning or in terms of entrepreneurship. It is known as a brand that needs to be sought and maintained in accordance with the existence of the Quraisy tribe, which acts as a symbol that has a noble value affecting the trust of the wider community. ${ }^{43}$

In a classical interpretation, Quraisy is defined as the name of an honorable tribe in the Arab Jahiliyah era that are the descendants of an-Nadhr bin Kinanah. However, modern interpretations defined it as a symbol of the importance of making branding that can be sold in the business world. It means that a quality product is not enough, however, it needs to build a big name as a sales technique.

In the entrepreneurial world, a brand is an asset that can drive value and boost sales. Its existence as a building and moving identity is used to define it as a strategic place that is large, wellknown, friendly, and fun. Therefore, it can also be created by making well-known brands with clear marketing strategies. In obtaining branding, an entrepreneur needs to make a strong promotion and quality that is not in doubt.

Finally, an eclectic study of Q.S. Quraisy, was carried out by choosing the interpretation of classical scholars in line with the mission of entrepreneurial teachings. According to several studies, the interpretation of ilaf with the meaning of mahabbah (loving) and al-'adah al-ma'lufah commonly known habits is relevant to the meaning of experience in entrepreneurship.

The word ilaf can also be interpreted as habit, pleasure, experience, preparation, and agreement. In the past, the Quraisy had a secure agreement, also known as "mu'ahadah ilaf" with several tribes to be guaranteed security while trading. The meaning of ilaf in Q.S. Quraisy was that they were accustomed to continuous

\footnotetext{
${ }^{43}$ Departemen Agama RI, Al-Quran Dan Tafsirnya.
} 
traveling without worries. Ibn al-Arabi stated that ashabu al-ilaf had four people, including, Hashim, Abdu Shams, al-Mutallib, and Naufal Bani Abdi Manaf that were able to properly build relationships, care for the neighbor, and guarantee the safety of Quraisy inhabitants to trade abroad. Therefore, they were nicknamed al-muhajirin, which means protectors/saviors. ${ }^{44}$

Hasyim had a relationship with a Roman king, while Naufal's relationship was with the Persian. Abdu Shams established a relationship with king Najjasyi, while, al-Muttalib relates to Bani Himyar around Mecca. The Quraisy traders received security guarantees to travel and trade to the four different regions because of their relationship. ${ }^{45}$

In the business world, ilaf is intended as work experience, that is resilient in carrying out business. As the interpretation released by the Indonesian Ministry of Religion explains that ilaf is used for trading factors that are formed through training, upbringing, and hereditary traditions. It produces an experience by shaping a person's abilities and character. Anyone that wants to succeed in business and entrepreneurship needs first to understand their work. ${ }^{46}$ Those that carry out businesses on the basis of hobbies and likes continue to look for experience and are resilient with a greater chance of success.

Conversely, when people feel unhappy and depressed with their work every day without trying to enjoy or animate their businesses, failure surely awaits them. Therefore, the term experience is the best teacher is true. ${ }^{47}$ Especially in the current era, by not only relying on diplomas in carry out their businesses, rather on the creation, attitude, expertise, and real work considered in the entrepreneurial world.

${ }^{44}$ Muhamad bin Mukrim Ibn Mandzur, Lisan al-'Arab (Bairut: Dar Shadir, 1999).

${ }^{45}$ Ibn Mandzur.

${ }^{46}$ Departemen Agama RI, Al-Quran Dan Tafsirnya.

${ }^{47}$ Robert J. Thomas and Peter Cheese, "Leadership: Experience Is the Best Teacher," Strategy and Leadership, 2005, 1, doi:10.1108/10878570510594424. 
Furthermore, the interpretation of the word Quraisy relevant to the entrepreneurship meaning in Qur'an is the possession of at-takasub and al-'amal. Several classical interpreters defined the word Quraisy as at-takasub, which means trying, working or even entrepreneurial. ${ }^{48}$ However, the meaning moved from the nation's big name into the at-takasub, which uses a hermeneutic analysis. Therefore, the relevance of at-takasub is similar to the entrepreneurship manifestation in the present context.

Rihlah, which is interpreted as a journey for business, is relevant in relation to the shifting meaning for_carrying out comparative studies or business development with a trial and error system. An entrepreneur needs to be brave, creative, tenacious, patient, always willing to learn, look for many opportunities, and smart utilizing marketing terms. ${ }^{49}$

Rihlah is interpreted as a journey for the business development world, carried out by comparative studies, of the market, adding insight, looking for links, and cooperation. This means that an entrepreneur needs to develop by continually learning because stopping is a sign of failure. ${ }^{50}$

The word worship can also be upgraded, to mean vertical in nature, and horizontal in humanity. The last verse, which is the most important point in Islamic entrepreneurship, is worshiping Baitullah's owner by carrying out His commands, adhering to prohibitions, and always praying and hoping in Him. This is the most important point in the world of Islamic entrepreneurship. Therefore, assuming it is absent, Islamic entrepreneurship becomes similar to the other business world. ${ }^{51}$

The act of worship is similar to developing piety. According to Rasyid Ridha piety was not only enough to carry out orders and

${ }^{48} \mathrm{Al}-\mathrm{Harari}$, Hadaiq ar-Ruh wa ar-Raihan.

${ }^{49}$ O. Syarifah, Abu M.Y., Raziah B.H., and Azizah M.T., "Successful Women Enterpreneur : Islamic Life Practice," International Journal of Islamic Business, 2018, 2.

${ }^{50}$ Sri Hartini, "Peran Inovasi: Pengembangan Kualitas Produk Dan Kinerja Bisnis," Jurnal Manajemen Dan Kewirausahaan, 2012, 1, doi:10.9744/jmk.14.1.83-90.

${ }^{51}$ Baladina, "Membangun Konsep Enterpreneurship Islam." 
leave the prohibition for the hereafter happiness alone. Therefore, Ridha also added the importance of avoiding some things causing damage to life in this world. For example, worship and piety are not enough for an entrepreneur because they need to pray and ask God with tawaf in order to obtain the needed productivity, tenacity, and creativity. ${ }^{52}$

However, the piety and worship meanings for entrepreneurs are to develop themselves, always look for inhibiting factors, study well, and avoid similar mistakes. Furthermore, businessmen have been carrying out worship and piety according to their profession. Therefore, worship experts in their relevance to entrepreneurs need to know the job description and rules of God's social law. ${ }^{53}$

Understanding the meaning of piety and worship is certainly humanistic, because worship no longer dwells on divine vertical affairs, rather it is dynamic. Piety and worship changes in accordance with time, challenges, obstacles, supporting factors, obstacles and opportunities.

When explored more deeply, the spirit of this meaning has been echoed by Islamic thinkers such as Muhammad al-Ghazali by stating that worship varies depending on the perpetrator's job. For example, the worship of students is to study earnestly, while those of teachers and educators are to devote time, to obtain the present method of assisting students. Government service is always making people's welfare, therefore, workers find a way to get halal wealth. This was concluded by al-Qasimi. ${ }^{54}$

Based on the selection of religious interpretations as the figures opinions, the appropriate spirit of humanism theological interpretation in dissecting the Q.S. Quraisy was obtained in this study. The Quraisy and aspiration of Hassan Hanafi were used to open the eyes of religious texts readers into an unavoidable reality.

\footnotetext{
${ }^{52}$ Rasyid Ridha, Tafsir al-Manar (Beirut: Dar Syuruq, 1999), 15.

${ }^{53}$ Jamaluddin al-Qasimi, Mau'idzah al-Mu'minin (Bairut: Dar al-Kutub al-'Ilmiyah, 2005), 88.

${ }^{54}$ Al-Qasimi.
} 


\section{Conclusion}

In conclusion, the development of Quraisy in accordance with classical and modern interpretation is based on the theology of humanism by Hassan Hanafi. The classical interpretation means that ilaf is a custom practiced by the Arabs in trading, whereas the modern interpretation analyzes it as a trading experience, with an entrepreneurial spirit and potential. According to the classical interpretation the word Quraisy is the name of a large tribe, while the modern interpretation defined as the act of branding business products. Furthermore, the classical interpretation stated that rihlah is a journey to trade, while the modern sees it as the entrepreneur's tenacity to build their business. The classical interpretation defined worship as a vertical relationship with God and the modern interpretation touches on the theology of humanism by linking worship to the horizontal trade relationship. 


\section{REFERENCES}

Abidin, Zainal and Ari Wahyu Prananta. "Kajian Etos Kerja Islami Dalam Menumbuhkan Jiwa Wirausaha Santri." Happiness: Journal of Psychology and Islamic Science 3, no. 2 (2019).

Amstrong, Karen. Muhamad Sang Nabi: Sebuah Biografi Kritis. Surabaya: Risalah Gusti, 2011.

Baladina, Nur. "Membangun Konsep Enterpreneurship Islam." ULUL ALBAB: Jurnal Studi Islam 13, no. 2 (2013): 123-36.

al-Bukhari, Abdullah bin Masud. at-Taudhih fi Halli Ghawamidh atTanqih. Bairut: Dar al-Kutub al-'Ilmiyah, 2014.

Dalmeri. "Membayangkan Islam Dan Toleransi Di Era Postmodernitas: Kritik Terhadap Rasionalisme Kaum Muslim Modernis." HARMONI: Jurnal Multikultural and Multireligius 9, no. 35 (2010).

Davis, Miles K. "Entrepreneurship: an Islamic Perspective." International Journal Entrepreneurship and Small Business 20, no. 2 (2013): 64-66.

Departemen Agama RI. Al-Qur'an Dan Tafsirnya (Edisi Yang Disempurnakan), Jilid 10. Jakarta: Widya Cahaya, 2011.

Falah, Riza Zahriyal, and Irzum Farihah. "Pemikiran Teologi Hassan Hanafi." Fikrah: Jurnal Ilmu Aqidah Dan Studi Keagamaan, 2016. doi:10.21043/fikrah.v3i1.1833.

al-Farmawi, Abdul Hayy. al-Bidayah fi at-Tafsir Maudhu'i: Dirasah Manhajiyyah Maudhuiyyah. Mesir: Mathba'ah al-Hadharah al-'Arabiyyah, 1997.

Gümüsay, Ali Aslan. "Entrepreneurship from an Islamic Perspective.” Journal of Business Ethics, 2015. doi:10.1007/s10551-0142223-7.

Hanafi, Hassan. Islamologi 3: Dari Teosentris Ke Antroposentris. Yogyakarta: LKiS, 2004.

Hanif, Muh. "Hermeneutika Hans-Georg Gadamer Dan Signifikansinya Terhadap Penafsiran Al-Qur'an." Maghza 7, no. 40 (2013). 
al-Harari, Amin bin Abdullah. Hadaiq ar-Ruh wa ar-Raihan. Beirut: Dar Thauq Najah, 2001.

Hartini, Sri. "Peran Inovasi: Pengembangan Kualitas Produk Dan Kinerja Bisnis." Jurnal Manajemen Dan Kewirausahaan, 2012. doi:10.9744/jmk.14.1.83-90.

Hitti, Philip K. History of the Arabs. Jakarta: Serambi, 2002.

Ibn Katsir, Abu al-Fida Ismail. Tafsir Al-Qur'an Al-'Azhim. Riyadh: Dar Taiba, 2006.

Ibnu Mandzur, Muhamad bin Mukrim. Lisan al-'Arab. Beirut: Dar Shadir, 1999.

al-Jamal, Sulaiman bin Umar bin Manshur. al-Futuhat al-Ilahiyyah. Beirut: Darul Kutub al-'Ilmiyyah, 2018.

Juhanis. "Filosofi Wirausaha Nabi Muhamad." SULESANA: Jurnal Wawasan Keislaman 8, no. 1 (2013).

Kementrian Agama RI Lajnah Pentashihan Mushaf Al-Qur'an. AlQur'an Dan Terjemahnya. Bandung: Penerbit J-ART, 2005.

al-Maraghi, Ahmad Musthafa al-. Tafsir al-Maraghi, Volume 18. Mesir: Musthafa al-Babi al-Halabi, 1946.

Maulana, Fikri. "Pendidikan Kewirausahaan Dalam Islam." IQ (Ilmu Al-Qur'an): Jurnal Pendidikan Islam 2, no. 1 (2019): 30-44.

al-Mawardi, Ali bin Muhammad bin Muhammad. an-Nukat wa al'Uyun. Beirut: Dar al-Kutub al-'Ilmiyah, 2010.

Nastain, Muhamad. "Branding Dan Eksistensi Produk: Kajian Teoritik Konsep Branding Dan Tantangan Eksistensi Produk." CHANNEL: Jurnal Komunikasi Universitas Ahmad Dahlan Yogyakarta 5, no. 1 (2017): 14-26.

Peters, Francis E. Muhammad and the Origins of Islam. Amerika Serikat: SUNY Press, 1994.

al-Qasimi, Jamaluddin. Mau'idzah al-Mu'minin. Beirut: Dar al-Kutub al-'Ilmiyah, 2005.

ar-Razi, Fakhr ad-Din. Mafatih al-Ghaib. Beirut: Dar al-Kutub al'Ilmiyyah, 2015. 
Ridha, Rasyid. Tafsir al-Manar. Beirut: Dar Syuruq, 1999.

Ridwan, A.H. Reformasi Intelektual Islam: Pemikiran Hassan Hanafi Tentang Reaktualisasi Tradisi Keilmuan Islam. Yogyakarta: ITTAQA Press, 1998.

as-Samarqandi, Abu al-Lais Nashr bin Muhamad. Bahru al-'Ulum. Beirut: Dar al-Kutub al-'Ilmiyyah, 1993.

Shihab, M. Quraish. Tafsir al-Misbah. Jakarta: Lentera Hati, 2017.

Sholehuddin, Moh. "Metode Ushul Fiqih Hasan Hanafi." Journal de Jure, 2011. doi:10.18860/j-fsh.v3i2.2148.

Sjaroni. "Studi Tafsir Tematik." Jurnal Studi Islam: Pancawahana, 2014.

Syarifah, M.Y., B.H. Abu, M.T. Raziah, and O. Azizah. "Successful Women Enterpreneur: Islamic Life Practice." International Journal of Islamic Business, 2018.

Syarifuddin. "Analisis Sejarah Dagang Muhammad Pra Kerasulan." Jurnal Ilmiah al-Syirah 5, no. 2 (2016).

asy-Syaukani, Muhamad bin Ali. Fathu al-Qadir. Beirut: Dar al-Kalim ath-Thayyib, 1994.

ath-Thabari, Abu Ja'far Muhammad ibn Jarir. Jami' al-Bayan 'an Ta‘wil Ay Al-Qur'an. Giza: Dar al-Hijr, 2001.

Thomas, Robert J. and Peter Cheese. "Leadership: Experience Is the Best Teacher." Strategy and Leadership, 2005. doi:10.1108/10878570510594424.

Zainuddin, Ahmad. "Dimensi Sosial Tawhid: Konstruksi Jaringan Relasional Islam Perspektif Hassan Hanafi." MIYAH: Jurnal Studi Islam 13, no. 1 (2019): 58-81.

Zayyadi, Ahmad. "Pendekatan Hermeneutika Al-Qur'an Kontemporer Nashr Hamid Abu Zaid." MAGHZA: Jurnal Ilmu Al-Qur'an Dan Tafsir, 2018. doi:10.24090/maghza.v2i1.1563.

az-Zuhaili, Wahbah. Tafsir al-Munir fi al-'Aqidah wa asy-Syari'ah wa al-Manhaj. Damaskus: Dar al-Fikr, 2009. 